\title{
Electrophysiological Characterization of Voltage-Gated Currents in Defined Taste Cell Types of Mice
}

\author{
Kathryn F. Medler, ${ }^{1,2}$ Robert F. Margolskee, ${ }^{3}$ and Sue C. Kinnamon ${ }^{1,2}$ \\ ${ }^{1}$ Department of Biomedical Sciences, Colorado State University, Fort Collins, Colorado 80523, ${ }^{2}$ Rocky Mountain Taste and Smell Center, University of \\ Colorado Health Sciences Center, Denver, Colorado 80262, and ${ }^{3}$ Howard Hughes Medical Institute and Department of Physiology and Biophysics, Mount \\ Sinai School of Medicine, New York, New York 10029
}

\begin{abstract}
Despite extensive immunological characterization of the cells within taste buds, little is known about the functional significance of the different cell types. In this study, we use taste cells isolated from mouse vallate and foliate papillae to characterize voltage-gated currents in the three principal elongate types of taste cells: type I, II, and III. Cell types are identified by using antibodies to external epitopes [antigen $\mathrm{H}$ for type I cells, antigen A for type II cells, and neural cell adhesion molecule (NCAM) for type III cells]. In addition, we identify the subset of type II cells that contains $\alpha$-gustducin, a G-protein involved in bitter transduction, by using transgenic mice expressing green fluorescent protein under the control of the gustducin promoter. Our results indicate that antigen $\mathrm{H}$-immunoreactive (-IR) cells and many of the antigen A-IR cells have small voltage-gated inward $\mathrm{Na}^{+}$and outward $\mathrm{K}^{+}$currents but no voltage-gated $\mathrm{Ca}^{2+}$ currents. In contrast, a subset of antigen A-IR cells and all NCAM-IR cells have large inward $\mathrm{Na}^{+}$and outward $\mathrm{K}^{+}$currents as well as voltage-gated $\mathrm{Ca}^{2+}$ currents. Unexpectedly, all gustducin-expressing cells lacked voltage-gated $\mathrm{Ca}^{2+}$ currents, suggesting that these cells use mechanisms other than classical synapses to communicate signals to the brain.
\end{abstract}

Key words: taste-cell types; gustducin; voltage-gated currents; patch-clamp electrophysiology; immunocytochemistry; taste transduction

\section{Introduction}

Taste buds are heterogeneous populations of cells that have both neuronal and epithelial properties. Taste cells are electrically excitable and can synapse with nerve fibers, but like epithelial cells, taste cells undergo continuous replacement (Farbman, 1980). Ultrastructural features have been used to categorize taste cells into cell types, although some features vary in different species (Murray, 1973; Kinnamon et al., 1985; Pumplin et al., 1997). The following cell types have been described in mammalian taste buds: basal cells, type I (dark) cells, type II (light) cells, and type III cells (Murray, 1969, 1973). Basal cells are proliferative cells that give rise to new taste cells as turnover occurs. Type I cells have an electron-dense cytoplasm, irregular-shaped nuclei, and long microvilli that extend to the taste pore. Type II cells have an electron-lucent cytoplasm, circular nuclei, and numerous short microvilli (Kinnamon et al., 1985; Pumplin et al., 1997). Type III cells, which are sometimes grouped with light cells based on light microscopic criteria, have a single blunt microvillus, irregular nuclei, and dense cored vesicles (Murray 1969, 1973).

Immunocytochemical studies in rats show that certain histochemical markers are associated with each cell type (Takeda et al., 1992; Pumplin et al., 1997; Yee et al., 2001). The blood group carbohydrate epitope antigen $\mathrm{H}$ is expressed primarily on type I cells (Pumplin et al., 1997). No single marker characterizes all type II cells, but several markers are found only in type II cells.

Received Aug. 5, 2002; revised Dec. 23, 2002; accepted Jan. 17, 2003.

This work was supported by National Institutes of Health Grants DC00766 and DC00244 to S.C.K. We thank T. Clapp for assistance in obtaining confocal images and T. Finger, J. Kinnamon, and L. Stone for a critical reading of this manuscript.

Correspondence should be addressed to Kathryn Medler, Department of Biomedical Sciences, Colorado State University, Fort Collins, C0 80523. E-mail: Kathryn.Medler@colostate.edu.

Copyright $\odot 2003$ Society for Neuroscience $\quad 0270-6474 / 03 / 232608-10 \$ 15.00 / 0$
One of these, $\alpha$-gustducin, a G-protein involved in bitter transduction (Wong et al., 1996; Chandrashekar et al., 2000), is confined to a subset of type II cells (Yang et al., 2000b). Antigen A, another blood-group epitope, is expressed on a subgroup of type II cells that have some overlap with the gustducin-expressing cells (Pumplin et al., 1999). Neural cell adhesion molecule (NCAM) is a cell surface marker that labels type III cells (Takeda et al., 1992).

The functional differences of the cell types are poorly understood. It is not clear whether all cell types serve as taste receptors, or whether some serve only a supporting role in the taste bud. In addition, controversy exists as to whether all cell types communicate directly with gustatory nerve fibers. Currently, gustducinexpressing type II cells are the only cells associated with the transduction of a particular taste quality, but how these cells communicate with the nervous system is unknown. Type III cells synapse with afferent nerve fibers (Murray, 1969, 1973; Kinnamon et al., 1985; Royer and Kinnamon, 1988), but whether these cells transduce taste stimuli is unclear. We use the whole-cell patch-clamp technique (Hamill et al., 1981) to characterize membrane properties of mouse taste cells identified by cell surface markers and green fluorescent protein (GFP) expression driven by the gustducin promoter (Huang et al., 1999; Wong et al., 1999). These data provide the first functional characterization of defined mammalian taste cell types and suggest that not all taste receptor cells communicate taste information to the nervous system in conventional ways.

\section{Materials and Methods}

Immunocytochemical analysis. To assess the degree of coexpression for our various markers, we performed dual-label immunocytochemistry on fixed lingual tissues. For these studies, tongues were removed and immersion-fixed in 4\% paraformaldehyde in phosphate buffer ( $\mathrm{PB}), \mathrm{pH}$ 7.2 , and then cryoprotected with $20 \%$ sucrose in PB overnight at $4^{\circ} \mathrm{C}$. 
Forty micrometer sections were cut on a cryostat and collected in PBS, $\mathrm{pH}$ 7.2. Sections were washed three times for $10 \mathrm{~min}$ each and put in blocking solution $(0.3 \%$ Triton X-100, $1 \%$ normal goat serum, and $1 \%$ bovine serum albumin in PBS) for $1-2 \mathrm{hr}$ at room temperature (RT). After blocking, sections were incubated overnight at $4^{\circ} \mathrm{C}$ with either anti-NCAM (1:250) (rabbit; Chemicon, Temecula, CA), anti-antigen A (1:50) (mouse; Dako, Carpinteria, CA), or anti-gustducin (1:250) (rabbit; Santa Cruz Biotechnology, Santa Cruz, CA) in blocking solution, or left in blocking solution alone. The following day, sections were washed three times for 10 min each with PBS and then incubated with the appropriate secondary antibody for $2 \mathrm{hr}$ at RT. Double-label experiments were incubated with Cy-5 anti-rabbit (1:250; Jackson ImmunoResearch, West Grove, PA) and FITC anti-mouse (1:100; Jackson ImmunoResearch) secondary antibodies. The single-label experiment was incubated with Cy-5 anti-rabbit (1:250). Sections were then washed with PBS three times for $10 \mathrm{~min}$ each and mounted using flouromount-6 (Southern Biotechnology, Birmingham, AL). Taste buds were viewed with an Olympus Optical (Tokyo, Japan) Fluoview laser-scanning confocal microscope, and images were captured with Fluoview software and processed using Adobe Photoshop 6.0 software (Adobe Systems, San Jose, $\mathrm{CA}$ ). Control experiments in which the primary antibody was omitted showed no labeling.

Isolation of taste-receptor cells. Adult transgenic mice in which the gustducin promoter drives expression of GFP were used for all experiments (Huang et al., 1999; Wong et al., 1999); the presence of GFP fluorescence was used to identify cells expressing the $\alpha$-gustducin protein. The background of these mice is predominantly C57BL/6J. Animals were cared for in compliance with the Colorado State University Animal Care and Use Committee.

Taste cells were isolated from lingual epithelium by a method adapted from Béhé et al. (1990). Briefly, tongues were removed from animals killed with $\mathrm{CO}_{2}$ and cervical dislocation. Approximately $100 \mu \mathrm{l}$ of an enzymatic solution containing $0.7 \mathrm{mg}$ of collagenase $\mathrm{B}, 3 \mathrm{mg}$ of dispase II (Roche Products, Indianapolis, IN), and $1 \mathrm{mg}$ of trypsin inhibitor (Type 1-S; Sigma, St. Louis, MO) per milliliter of Tyrode's solution (see below) was injected under the lingual epithelium. After 30-45 min of incubation, the epithelium was peeled from the underlying connective tissue and incubated in $\mathrm{Ca}^{2+}$-free Tyrode's for $30 \mathrm{~min}$. Foliate and circumvallate taste cells were removed with a capillary pipette using gentle suction and plated onto SuperfrostPlus (Fisher Scientific, Hanover Park, IL) glass slide chambers in regular Tyrode's. Taste cells were allowed to settle onto the slide for at least $10 \mathrm{~min}$ before any additional manipulations took place.

Identification of taste cells. Antibodies against cell-surface markers were used to identify cell types (see Fig. 2). The blood-group markers antigen $\mathrm{A}$ and antigen $\mathrm{H}$ were used to identify type II and type I cells, respectively (Pumplin et al., 1997, 1999). Although antigen A has been shown to label only type II cells, labeling by antigen $\mathrm{H}$ has not been as well defined. Other work (Takeda et al., 1992; Yee et al., 2001) has shown that NCAM is expressed by type III cells. Plated cells were identified for subsequent patch-clamp experiments by immunoreactivity for one of these markers. Antibodies to blood group epitopes (mouse anti-antigen A or antiantigen H; Dako) were each diluted 1:25 with Tyrode's and incubated with the plated cells for $10 \mathrm{~min}$. Secondary antibody (1:25) (rhodamine red $\mathrm{X}$ anti-mouse $\mathrm{F}\left(\mathrm{ab}^{\prime}\right)_{2}$ fragment; Jackson ImmunoResearch) was then added for $20 \mathrm{~min}$ before cells were washed. Antibody to NCAM (rabbit anti-NCAM; Chemicon) was diluted 1:50 and incubated with the cells for $10 \mathrm{~min}$. Secondary antibody $(1: 25)$ (rhodamine red $\mathrm{X}$ anti-rabbit $\mathrm{F}\left(\mathrm{ab}^{\prime}\right)_{2}$ fragment; Jackson ImmunoResearch) was then added for $20 \mathrm{~min}$ before cells were washed. Cells were viewed with a Nikon (Tokyo, Japan) Diaphot 200 inverted microscope fitted with Hoffman optics (Hoffmann-La Roche, Nutley, NJ). Labeled cells were photographed using the Spot Insight camera (Diagnostic Instruments, Sterling Heights, MI). Control experiments in which fluorescent secondary antibodies were added to the plated cells showed no labeling.

Patch-clamp recordings. Voltage-dependent currents were measured using whole-cell patch-clamp (Hamill et al., 1981). Patch electrodes were pulled from soda-lime capillary tubes (Scientific Glass, Rockwood, TN) with a Flaming/Brown micropipette puller (model P-97; Sutter Instru- ments, Novato, CA). Pipette resistance ranged from 4 to $6 \mathrm{M} \Omega$ using a high $\mathrm{K}^{+}$intracellular solution, and seals of 1-5 G $\Omega$ were obtained using gentle suction. Entry into the cell was made with a $1 \mathrm{msec}$ depolarizing pulse to the pipette. Whole-cell currents were measured using an Axopatch 1D patch-clamp amplifier and recorded using pClamp8 software (Axon Instruments, Foster City, CA). Signals were filtered at $5 \mathrm{kHz}$ and digitized at $100 \mu \mathrm{sec}$. Records were neither leak subtracted nor compensated for series resistance, although series resistance was generally $<10 \mathrm{M} \Omega$.

Membrane capacitance was compensated electronically, and external solutions were delivered by gravity flow at a rate of $2-3 \mathrm{ml} / \mathrm{min}$. Voltagegated currents were elicited from a holding potential of $-80 \mathrm{mV}$ by 100 msec step depolarizations from -60 to $60 \mathrm{mV}$. Because voltage-gated $\mathrm{Ca}^{2+}$ currents run down with time, and because it is difficult to hold recordings for extended periods from these small cells, we estimated $\mathrm{Na}^{+}$ current and $\mathrm{K}^{+}$current amplitudes from the magnitude of the peak early inward and late outward currents, respectively, from the mixed wholecell current. This allowed us to maximize the total amount of information that could be obtained from single taste cells, so data from several cells could be combined for analysis. Less than 10 cells were omitted from analysis because of low resting potentials (less than $-20 \mathrm{mV}$ ). Voltagedependent inactivation of the $\mathrm{Na}^{+}$current was measured by subjecting taste cells to a $200 \mathrm{msec}$ depolarizing prepulse before activation of the current. The $\mathrm{Na}^{+}$current was measured at $-10 \mathrm{mV}$, and normalized current was plotted against prepulse potential and fitted with a Boltzman distribution. $\mathrm{Ca}^{2+}$ currents were measured with a minimum of $1 \mathrm{~min}$ between each recording to prevent voltage-dependent inactivation of the current. Initially, a high $\mathrm{Ba}^{2+}$ external solution was used to block $\mathrm{K}^{+}$ currents and determine whether $\mathrm{Ca}^{2+}$ currents were present. Later, a lower $\mathrm{Ba}^{2+}$ external solution was used to characterize the $\mathrm{Ca}^{2+}$ current.

All comparisons were made using an unpaired $t$ test; statistical significance was as follows: $p<0.05$. When average values are reported, SE is included.

Solutions. Normal Tyrode's contained the following (in mM): 140 $\mathrm{NaCl}, 5 \mathrm{KCl}, 1 \mathrm{MgCl}_{2}, 8 \mathrm{CaCl}_{2}, 10$ HEPES, 10 glucose, and 1 pyruvic acid. $\mathrm{Ca}^{2+}$-free Tyrode's contained the following (in mM): $140 \mathrm{NaCl}, 5 \mathrm{KCl}, 10$ HEPES, 2 EGTA, 2 BAPTA, 10 glucose, and 1 pyruvic acid. TEA external solution contained the following (in mM): $112 \mathrm{NaCl}, 20$ TEA-Cl, $5 \mathrm{KCl}, 1$ $\mathrm{MgCl}_{2}, 8 \mathrm{CaCl}_{2}, 10 \mathrm{HEPES}, 10$ glucose, and 1 pyruvic acid. Normal Tyrode's with $10 \mathrm{~mm}$ 4-aminopyridine (4-AP) was also used to characterize outward currents. High $\mathrm{Ba}^{2+}$ contained the following (in mM): 100 $\mathrm{BaCl}_{2}, 1 \mathrm{MgCl}_{2}, 10$ HEPES, 10 glucose, and 1 pyruvic acid. The lower$\mathrm{Ba}^{2+}$ external solution contained the following (in mM): 136 TEA, 10 $\mathrm{BaCl}_{2}, 1 \mathrm{MgCl}_{2}, 10$ HEPES, 10 glucose, and 1 pyruvic acid. All of the TEA and $\mathrm{Ba}^{2+}$ external solutions contained $200 \mathrm{~nm}$ tetrodotoxin to block voltage-gated $\mathrm{Na}^{+}$currents. All external solutions were used at a $\mathrm{pH}$ of 7.4, and, unless otherwise indicated, chemicals were purchased from Sigma.

A high- $\mathrm{K}^{+}$internal solution was used for most experiments and was composed of the following (in mM): $140 \mathrm{KCl}, 2 \mathrm{MgCl}_{2}, 1 \mathrm{CaCl}_{2}, 11$ EGTA, 10 HEPES, 1 ATP, and 0.4 GTP, pH 7.2. In some experiments, $\mathrm{CsCl}$ replaced $\mathrm{KCl}$ to block $\mathrm{K}^{+}$currents and reveal the presence of $\mathrm{Ca}^{2+}$ currents.

\section{Results}

\section{Identification of cell types}

Control immunocytochemical experiments were performed to determine how well GFP expression correlated with immunoreactivity to the gustducin protein. Figure $1 \mathrm{~A}$ shows sections obtained from the circumvallate papillae of the transgenic mice labeled with an antibody against $\alpha$-gustducin. Analysis of 38 taste buds from four GFP-positive mice (cells, 199) found that $82.9 \pm$ $2.2 \%$ of gustducin-immunoreactive (-IR) cells expressed GFP, whereas $88.8 \pm 3.3 \%$ of GFP-labeled cells were gustducinimmunoreactive. Although there was not $100 \%$ coexpression, we conclude that GFP-positive cells are representative of the population of type II gustducin-IR cells.

Because previous studies have grouped type II and type III 
cells as light cells (Pumplin et al., 1999), we double-labeled sections from circumvallate papillae with antibodies against NCAM and antigen A to determine whether these cell populations overlapped. Double-labeled experiments from two mice were subjected to quantitative analysis (taste buds, 49; cells, 442). Of the NCAM-labeled cells, $7.8 \pm 1.9 \%$ were also labeled with anti-antigen $\mathrm{A}$, and of the antigen A-labeled cells, $7.5 \pm 1.6 \%$ were positive for anti-NCAM (Fig. $1 B$ ). These data show that the markers label predominately separate cell populations.

Isolated taste cells from either the foliate or circumvallate papillae were plated within a recording chamber and then stained with antibodies against one of three external epitope markers. The blood group marker antigen $\mathrm{H}$ was used to identify dark (type I) cells (Fig. 2A) (Pumplin et al., 1997). Identification of type I (dark) cells using cell-surface markers is difficult because of the tendency of dark cells to project processes that wrap around other taste cells in the bud. Thus, expression of antigen $\mathrm{H}$ on some light cells cannot be ruled out (Pumplin et al., 1997, 1999). A different blood group marker, antigen A, was used to identify a subset of light (presumed type II) cells (Fig. 2B) (Pumplin et al., 1999). The expression of antigen A has been seen only on taste cells with mature spindle shapes and apical processes extending to the taste pore (Pumplin et al., 1999). In the circumvallate papillae, only light cells (types II and III) have this shape (Pumplin et al., 1997). GFP expression linked to the gustducin promoter identified the gustducin-expressing cells, another subset of type II cells (Huang et al., 1999). There was some minor overlap ( $\sim 7 \%)$ between these type II cell populations. Previous studies have shown that NCAM is not expressed by basal cells but only by mature taste cells, and that this expression is dependent on innervation of the taste bud (Smith et al., 1993, 1994). Nelson and Finger (1993) found that NCAM expression was found primarily on sites related to nerve cell contact. Studies that focused on characterizing the expression of NCAM by cell type concluded that NCAM is found on type III cells (Takeda et al., 1992; Yee et al., 2001). Thus, we used NCAM to identify putative type III cells.

\section{General characterization of voltage-gated currents}

In all cells, regardless of cell type, transient voltage-gated inward currents were completely and reversibly blocked by $200 \mathrm{~nm}$ tetrodotoxin (Fig. 3A), indicating that they are carried by $\mathrm{Na}^{+}$(Herness and Sun, 1995). Inward currents activated between -30 and $-20 \mathrm{mV}$, peaked between -10 and $0 \mathrm{mV}$, and decreased with increasing depolarization toward the $\mathrm{Na}^{+}$equilibrium potential (Figs. 4-8). The actual reversal potential was shifted to the left of the $\mathrm{Na}^{+}$equilibrium potential because of activation of outward currents at positive voltages. In the presence of TEA external solution, currents were half inactivated at a prepulse potential of $-52 \mathrm{mV}$, which is comparable with that reported for rat taste cells (Béhé et al., 1990; Herness and Sun, 1995). Because the primary focus of this study was to relate overall current profiles to expression of $\mathrm{Ca}^{2+}$ current in each cell type, inward and outward currents were not isolated for analysis. Thus, some contamination of the inward and outward current occurred during the voltage steps when both types of current are activated.

Voltage-gated $\mathrm{Ca}^{2+}$ currents in taste cells were isolated by bathing the cells in $\mathrm{Ba}^{2+}$ external solution in the presence of TEA or with cesium internal solution. In all cases, $\mathrm{Ca}^{2+}$ currents were activated by strong depolarization, showed little or no inactivation with sustained depolarization, and were completely blocked by cadmium (Fig. $3 B$ ). $\mathrm{Ca}^{2+}$ currents were blocked to varying degrees in different taste cells by dihydropyridine antagonists and verapamil (data not shown).

The voltage-gated outward current was less consistent, as has been reported previously (Chen et al., 1996). However, in all cases, $\sim 80-90 \%$ of the outward current was blocked when $\mathrm{K}^{+}$ was replaced by cesium in the intracellular pipette solution (data not shown), indicating that these outward currents are carried by $\mathrm{K}^{+}$, with the small remaining current (Fig. $4 B$ ) likely carried by chloride (Wladkowski et al., 1998; Herness and Sun, 1999). We identified two different outward current profiles that correlated loosely with the different cell types, as discussed below. Many cells had an outward current that had slow activation kinetics, no inactivation, and a linear open channel current-voltage relationship (Fig. 3C). These currents were typical of a delayed rectifier $\mathrm{K}^{+}$channel. Many others had an outward current that activated more rapidly, inactivated with sustained depolarization, and occasionally exhibited a current-voltage relationship that showed saturation with increasing depolarization (Fig. 3D). The outward current profiles were not mutually exclusive; some cells had slowly activating currents that showed some saturation at higher voltages. $\mathrm{K}^{+}$currents in different taste cells were blocked to varying degrees by the $\mathrm{K}^{+}$channel blockers TEA (Fig. 3A) and 4-AP, but the percentage of block did not appear to correlate with cur- 


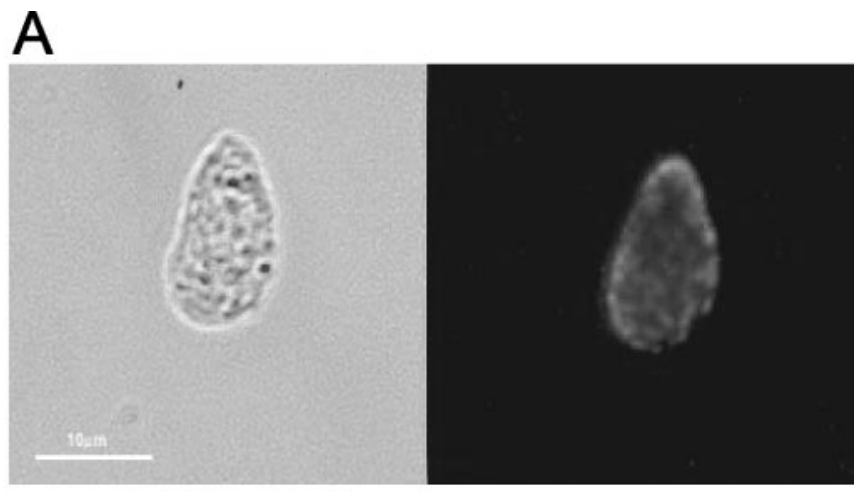

B
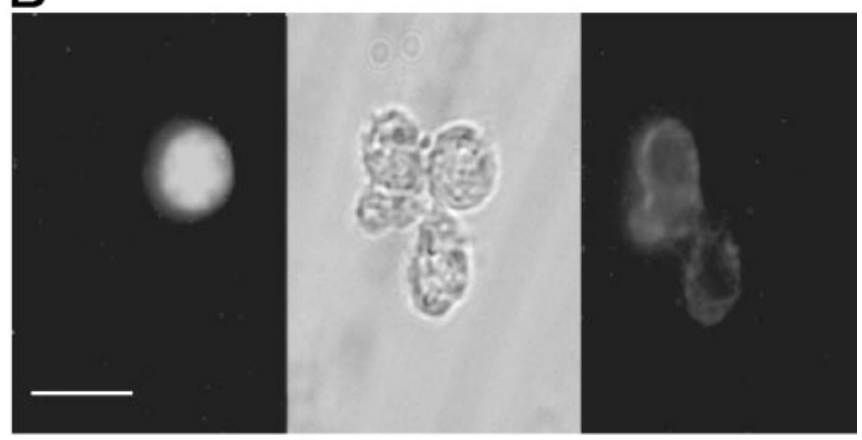

C

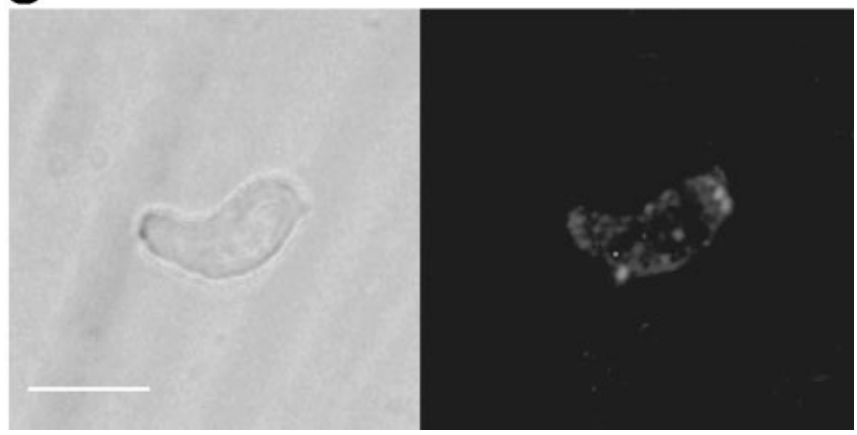

Figure 2. Photomicrographs of taste cells labeled with immunocytochemical markers and GFP. A, Antigen $\mathrm{H}$ immunoreactivity of a presumed type I cell. A bright-field micrograph of a taste cell immunoreactive for antigen $\mathrm{H}$ is shown on the left, with the fluorescence micrograph shown on the right. B, Presumed type II cells. The bright-field micrograph is in the middle, with GFP/gustducin fluorescence on the left and antigen A fluorescence on the right. C, NCAM immunoreactivity on a presumed type III cell. A bright-field micrograph of a cell that expresses NCAM is shown on the left, with the fluorescence labeling on the right. Scale bar, $10 \mu \mathrm{m}$.

rent profile or cell type. Thus, no additional effort was made to distinguish $\mathrm{K}^{+}$channels based on pharmacology.

\section{Analysis of antigen H-IR cells}

Antigen $\mathrm{H}$ was used to identify putative type I cells for whole-cell recordings (Pumplin et al., 1997). Two different populations of cells were present: those with a voltage-gated $\mathrm{Na}^{+}$current $(n=$ $11)$ and those without $(n=9)$. The $I-V$ profile shows that the inward current activated at $-30 \mathrm{mV}$, peaked at $-10 \mathrm{mV}$, and decreased with increasing depolarization (Fig. 4). Regardless of whether $\mathrm{Na}^{+}$currents were present, outward current profiles resembled those shown in Figure 3C; currents were slowly activating and showed little or no inactivation with sustained depolarization (Fig. 4A). There was saturation of the currents at depolarized potentials in a few cells. To test for the presence of

\section{A}
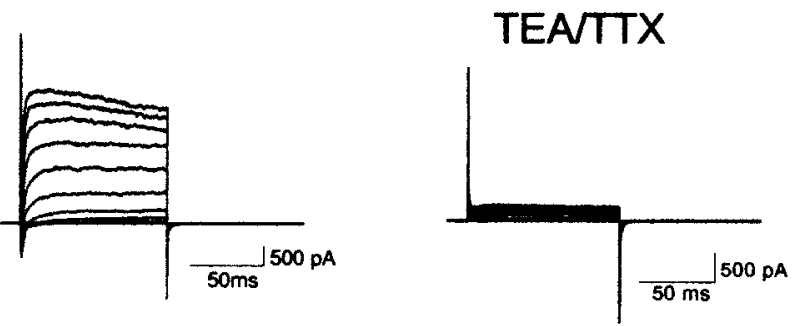

B

\section{$\mathrm{Ba}^{2+}$ external}
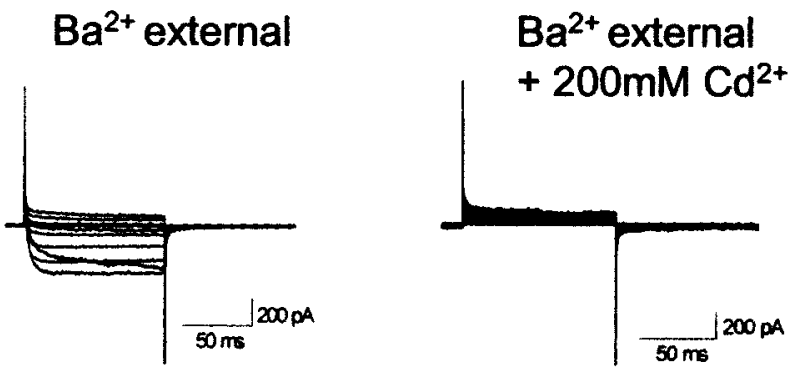
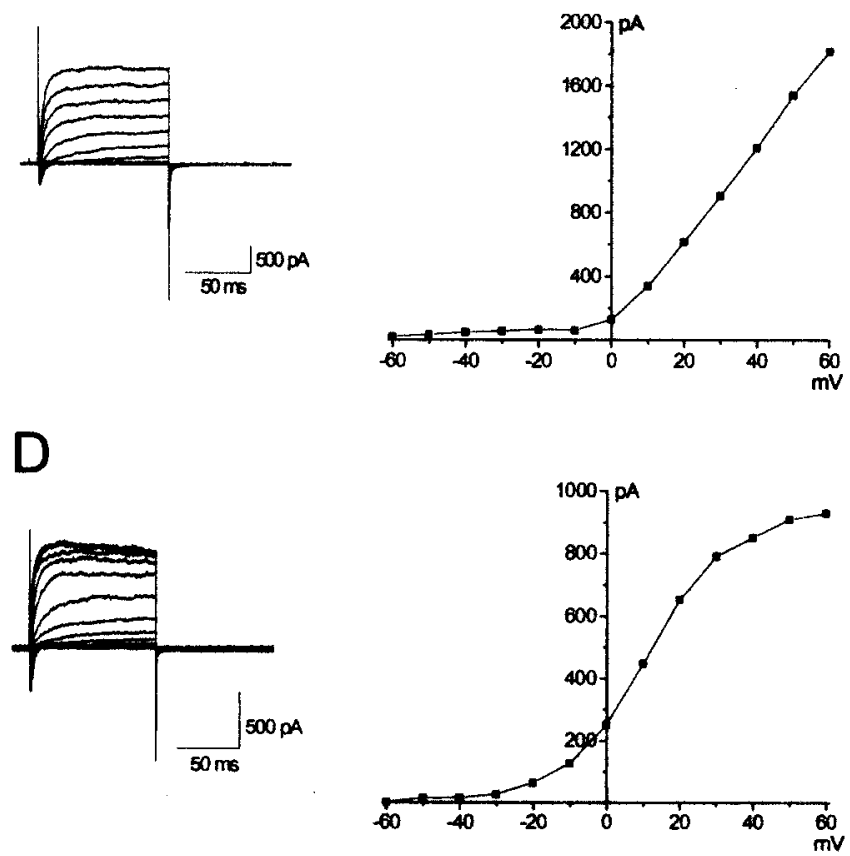

Figure 3. Representative current profiles. $A$, Current profiles in normal Tyrode's and TEA external solution with $200 \mathrm{~nm}$ tetrodotoxin (TTX). The inward current was completely blocked and most outward current was blocked, indicating that this inward current is carried by a voltage-gated $\mathrm{Na}^{+}$channel and that most of the outward current is carried by voltage-gated $\mathrm{K}^{+}$channels. $B$, Voltage-gated calcium currents in the presence of $\mathrm{Ba}^{2+}$ external. This inward current was completely blocked by $200 \mu \mathrm{m} \mathrm{Cd}^{2+}$, supporting the assumption that $\mathrm{Ba}^{2+}$ is passing through voltage-gated calcium channels. C, Representative current profile found in many taste cells that showed slow activation kinetics and no inactivation. The $I-V$ plot of the current profile is shown, which demonstrated a linear open-channel $I-V$ relationship. $D$, Representative outward current profile found in some taste cells, primarily those with voltage-gated $\mathrm{Ca}^{2+}$ currents. Activation was faster, and inactivation was evident. The $I-V$ plot of the current profile is shown, in which outward current showed saturation with large depolarizations. These profiles were not mutually exclusive and did not correlate strictly with cell type. In this and all subsequent figures, voltage-gated currents were elicited from a holding potential of $-80 \mathrm{mV}$ by 100 msec step depolarizations from -60 to $60 \mathrm{mV} ; \mathrm{K}^{+}$-current amplitude was measured at $60 \mathrm{mV}$. 


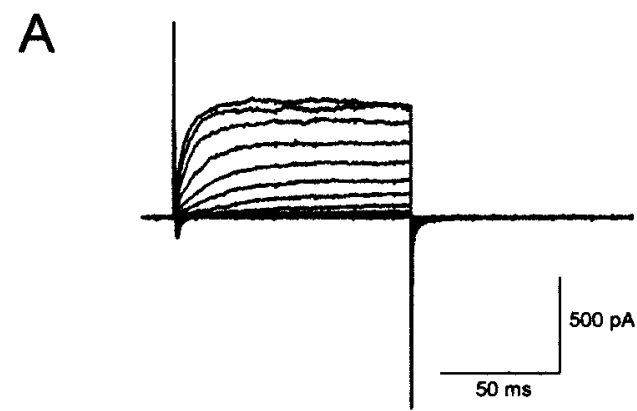

B
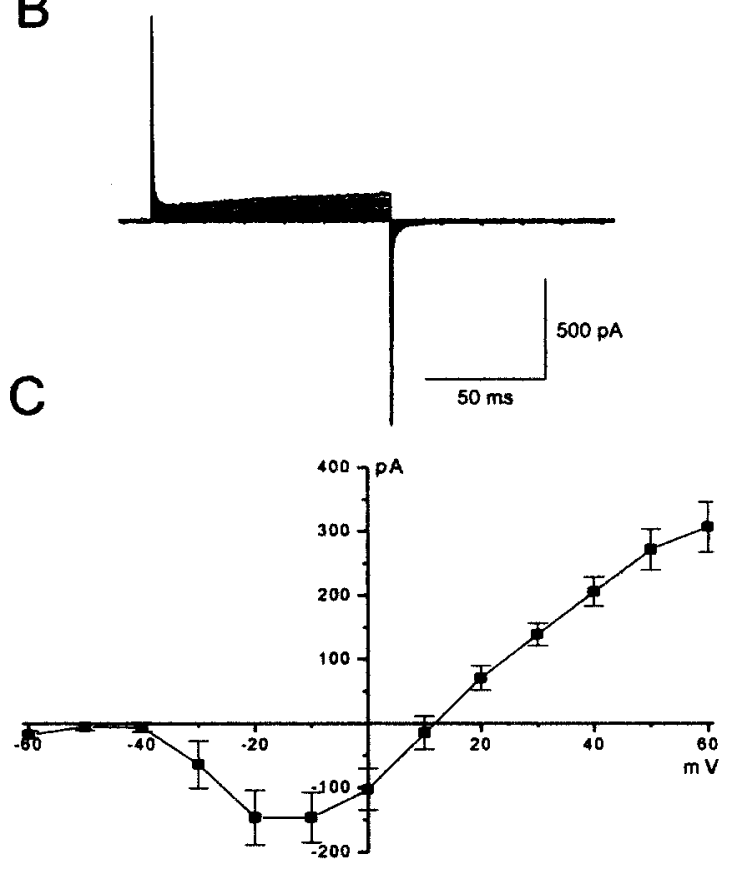

D

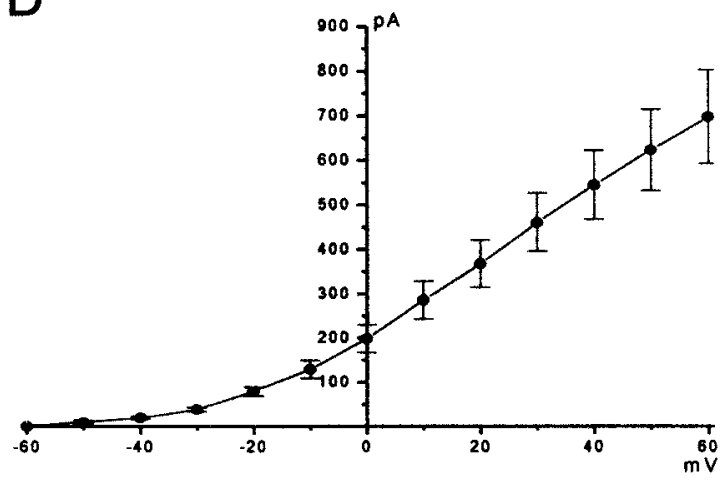

Figure 4. Representative voltage-gated currents from antigen H-IR (type I) cells. A, Recordings in Tyrode's show small voltage-gated inward currents followed by slowly activating $\mathrm{K}^{+}$currents of $<1$ $\mathrm{nA} . \mathrm{B}$, Voltage-gated currents in the presence of $\mathrm{Ba}^{2+}$ external solution to test for voltage-gated $\mathrm{Ca}^{2+}$ currents. None were detected, and most outward current was blocked. C, An average peak $\mathrm{I}-V$ plot for the voltage-gated inward current in all antigen $\mathrm{H}-\mathrm{IR}$ (type I) cells tested; SE is shown for this and subsequent figures. Activation began at $-30 \mathrm{mV}$, and current peaked between -10 and -20 $\mathrm{mV}$. Because $\mathrm{Na}^{+}$currents were measured in the presence of $\mathrm{K}^{+}$current, some of the outward current at depolarized voltages was carried by $\mathrm{K}^{+} . D$, An average $/-V$ plot for the voltage-gated $\mathrm{K}^{+}$ current of all cells tested. SE is shown for this and subsequent figures. Activation began at $-30 \mathrm{mV}$, and the open-channel $/-V$ relationship was linear.

voltage-gated $\mathrm{Ca}^{2+}$ currents, cells were bathed in $\mathrm{Ba}^{2+}$ external solution because $\mathrm{Ba}^{2+}$ permeates most voltage-gated $\mathrm{Ca}^{2+}$ channels without causing $\mathrm{Ca}^{2+}$-dependent inactivation (Hille, 2001). None of the antigen $\mathrm{H}$-IR cells tested had voltage-gated $\mathrm{Ca}^{2+}$ currents (Fig. $4 B$ ).
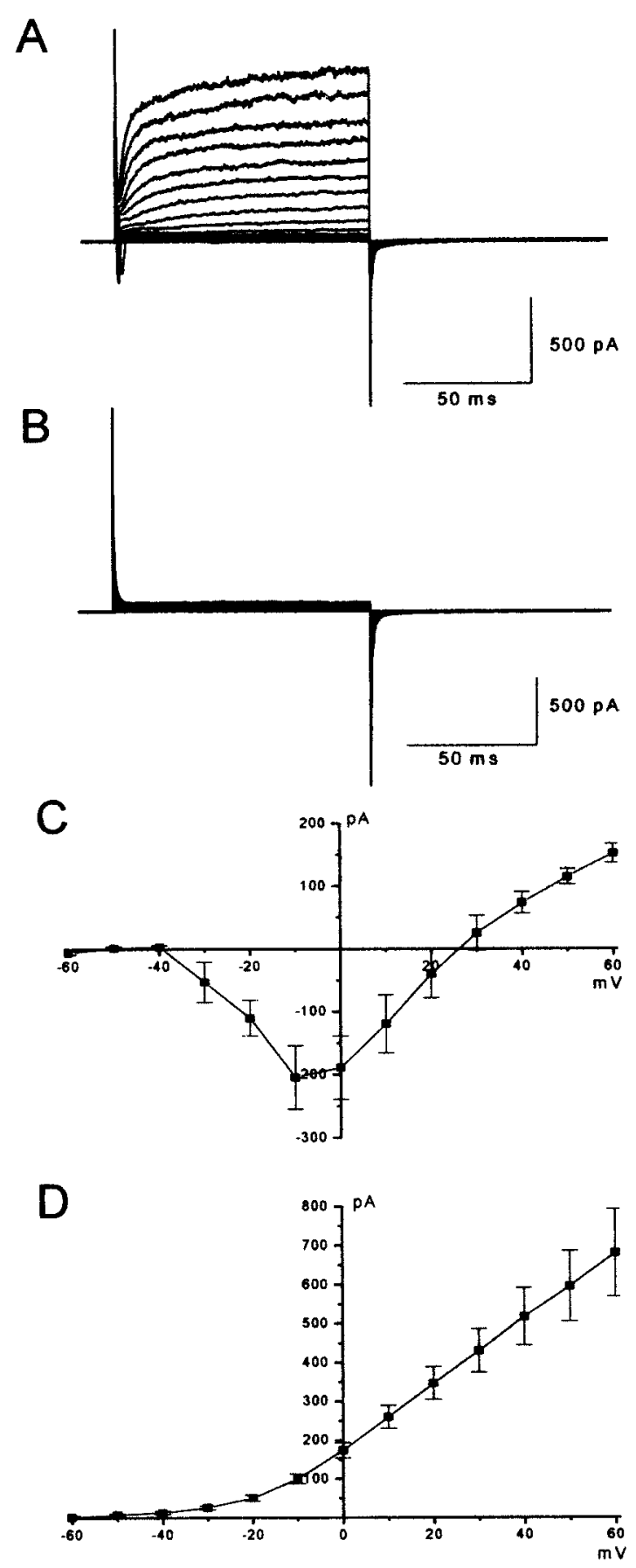

Figure 5. Representative voltage-gated currents in type II, GFP-positive (gustducinexpressing) taste cells. $A$, A small voltage-gated inward current was followed by a slowly activating $\mathrm{K}^{+}$current of $<1 \mathrm{nA}$. B, Voltage-gated currents in the presence of $\mathrm{Ba}^{2+}$ external solution to test for voltage-gated $\mathrm{Ca}^{2+}$ currents. None were detected in gustducin-expressing cells. $C$, An average $I-V$ plot for the voltage-gated inward current showed that the current began activating at $-40 \mathrm{mV}$ and peaked at $-10 \mathrm{mV}$. D, An average $I-V$ plot for the voltagegated $\mathrm{K}^{+}$current showed that the current began activating at $-30 \mathrm{mV}$ and that the openchannel $I-V$ relationship was linear.

General characteristics of antigen H-IR cells are summarized in Table 1. Although the lack of a voltage-gated $\mathrm{Na}^{+}$current was significantly different from the cells without $\mathrm{Na}^{+}$current $(p=$ 0.001 ), there was no significant difference in the outward current magnitude, activation kinetics $\left(T_{1 / 2}\right)$, resting potential, or input resistance between the two groups, so they were combined for comparison with other cell types. 


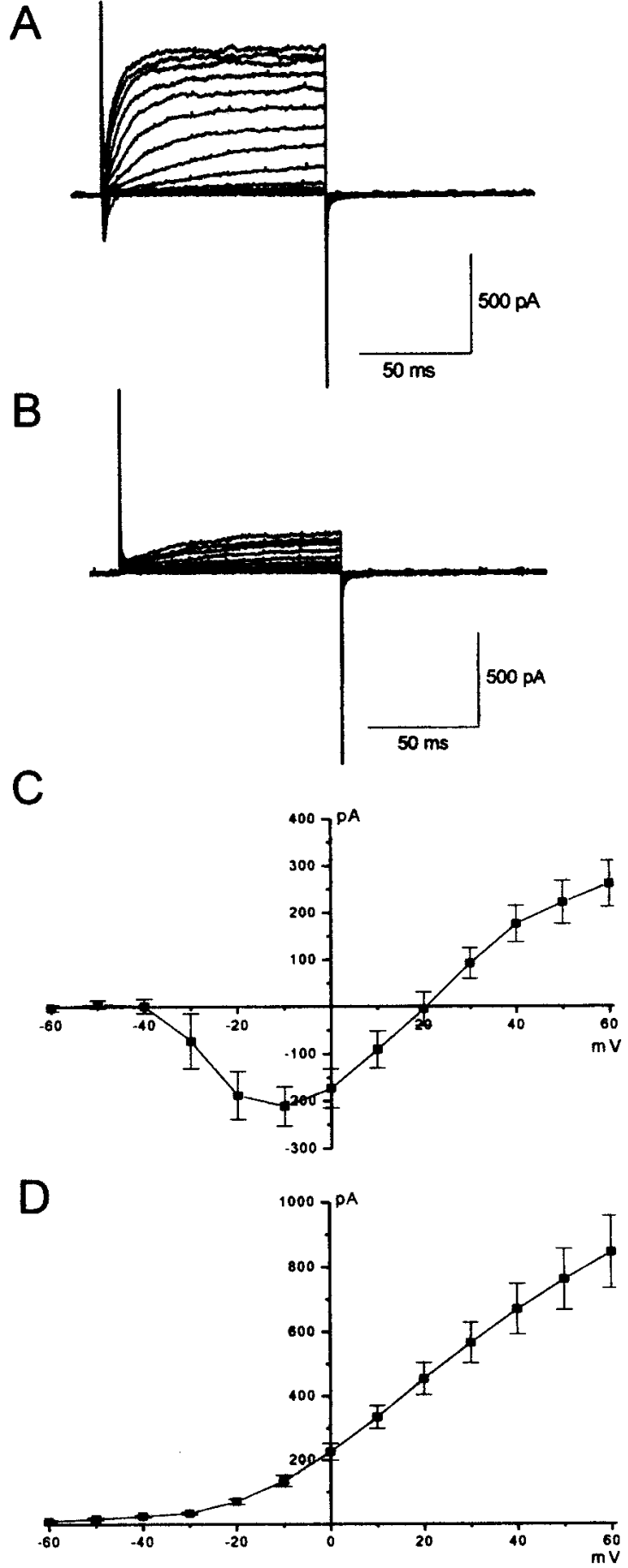

Figure 6. Representative voltage-gated currents from type II antigen A-IR cells that did not have voltage-gated $\mathrm{Ca}^{2+}$ currents. These cells represent $40 \%(n=17)$ of all antigen A-positive cells that were analyzed. $A$, Small voltage-gated $\mathrm{Na}^{+}$currents (peak, $-322 \mathrm{pA}$ ) were followed by a slowly activating $\mathrm{K}^{+}$current of $\sim 735 \mathrm{pA}$ at $60 \mathrm{mV}$. B, Voltage-gated currents in the presence of $\mathrm{Ba}^{2+}$ external solution to test for voltage-gated $\mathrm{Ca}^{2+}$ currents. None were detected in these cells. C, An average $I-V$ plot for the voltage-gated inward current showed that activation of the current began at $-40 \mathrm{mV}$ and peaked at $-10 \mathrm{mV}$. D, An average $I-V$ plot for the voltage-gated $\mathrm{K}^{+}$current showed that $\mathrm{K}^{+}$currents began activating at $-20 \mathrm{mV}$.

\section{Analysis of type II cells}

Gustducin-expressing cells

The first group of type II cells analyzed was the gustducinexpressing cells that were identified by targeting GFP-positive cells (Fig. $2 \mathrm{~B}$ ). Most cells had small voltage-gated inward currents

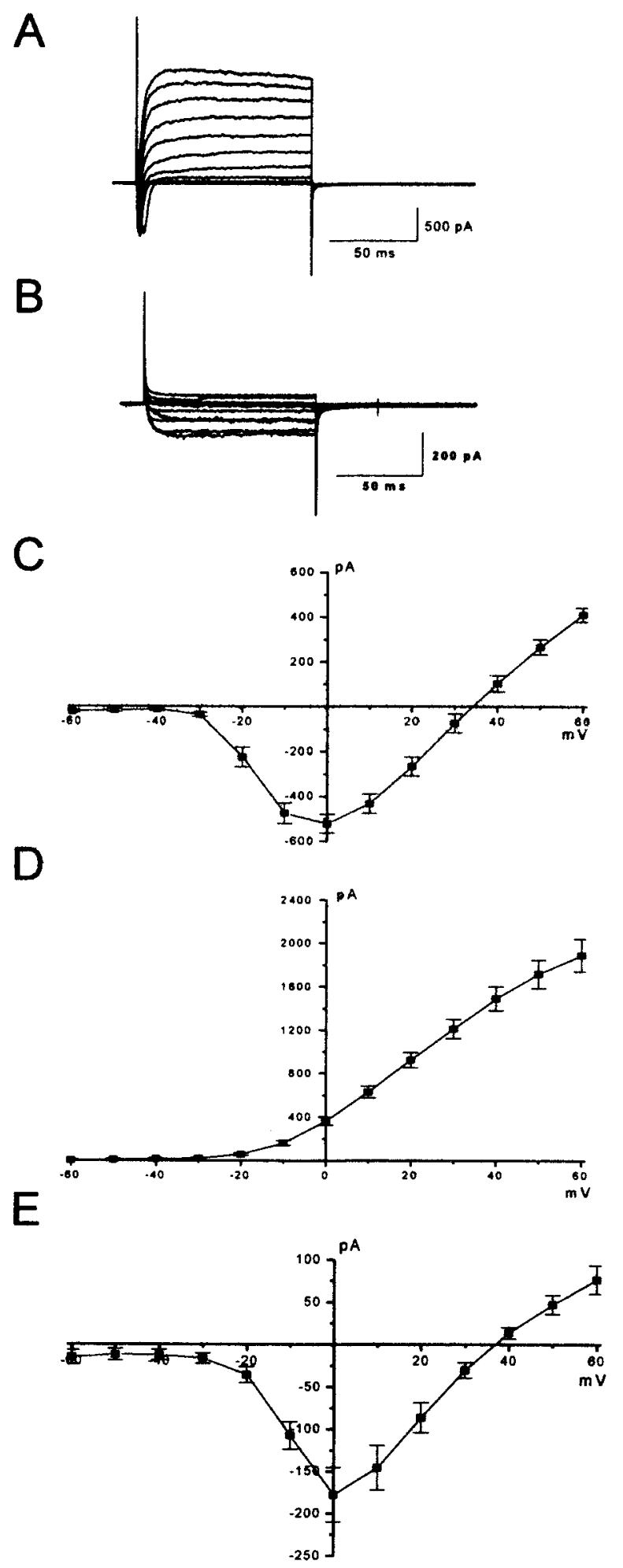

Figure 7. Representative voltage-gated currents from type II antigen A-IR cells that have voltage-gated $\mathrm{Ca}^{2+}$ currents. This represents $60 \%(n=25)$ of all antigen A-positive cells that were analyzed. $A$, Large voltage-gated inward currents (peak, $-607 \mathrm{pA}$ ) and rapidly activating and slowly inactivating $\mathrm{K}^{+}$currents $(1715 \mathrm{pA}$ at $60 \mathrm{mV})$ characterized this cell type. $B, \mathrm{Ba}^{2+}$ external solution revealed the presence of voltage-gated $\mathrm{Ca}^{2+}$ currents (average peak value, $-178 \mathrm{pA}$ ). C, An average $I-V$ plot for the voltage-gated inward current showed that the current began activating at $-20 \mathrm{mV}$ and peaked at $0 \mathrm{mV}$. $D$, An average $I-V$ plot for the voltage-gated $\mathrm{K}^{+}$current showed that this current activated at $-20 \mathrm{mV}$, with currents showing some saturation at depolarized voltages. $E_{1}$ An average $I-V$ plot for the voltage-gated $\mathrm{Ca}^{2+}$ currents in $10 \mathrm{~mm} \mathrm{Ba}^{2+}$ external solution. Currents began activating at $-20 \mathrm{mV}$ and peaked at $0 \mathrm{mV}$. 

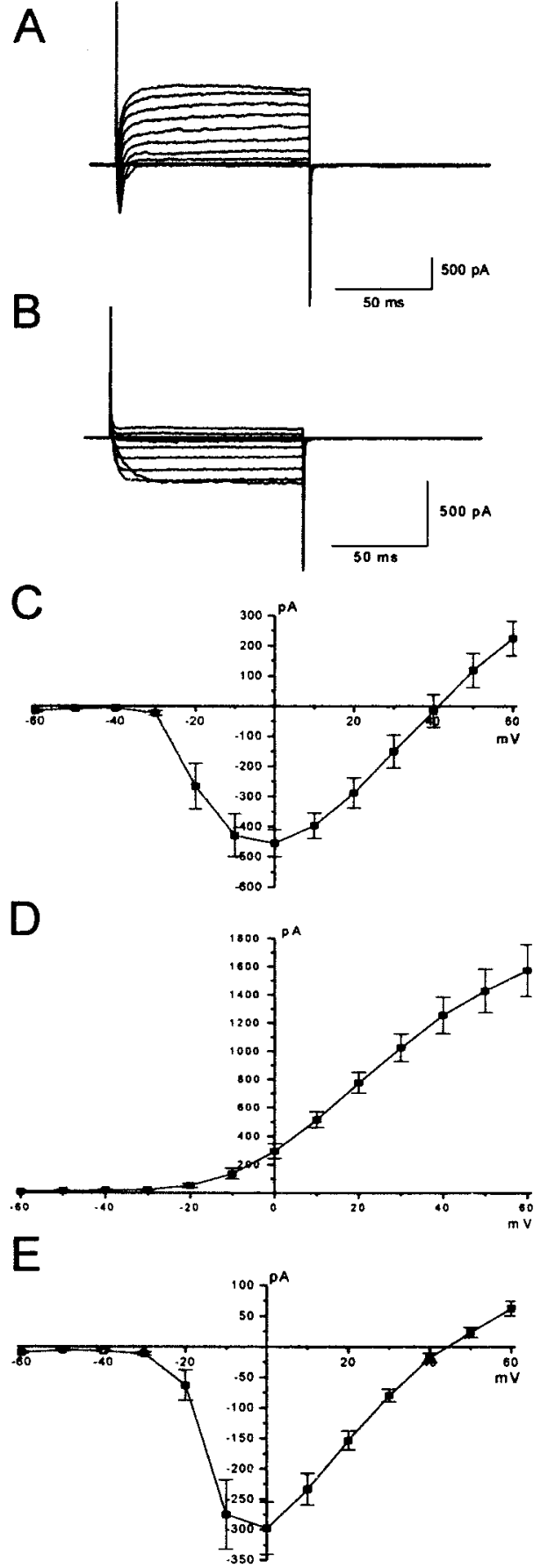

Figure 8. Representative voltage-gated currents from NCAM-IR (type III) cells. A, Large voltage-gated inward currents (peak, $-536 \mathrm{pA}$ ) and rapidly activating and slowly inactivating $\mathrm{K}^{+}$currents (1470 pA at $60 \mathrm{mV}$ ) characterized type III cells. B, Voltage-gated currents in the presence of $\mathrm{Ba}^{2+}$ external solution showed the presence of $\mathrm{Ca}^{2+}$ currents (peak current, $-315 \mathrm{pA}$ ). C, Average $I-V$ plot for the voltage-gated inward current showed that the current activated at $-20 \mathrm{mV}$ and peaked at $0 \mathrm{mV}$. D, Average $I-V$ plot for the voltage-gated outward current showed that current began activating at $-10 \mathrm{mV}$ and showed little saturation. $E_{i}$ Average $\mathrm{I}-V$ plot for the voltage-gated $\mathrm{Ca}^{2+}$ currents showed that current began activating at $-20 \mathrm{mV}$ and peaked at $0 \mathrm{mV}$.

(Fig. 5A), although 4 of 39 cells tested had no voltage-gated $\mathrm{Na}^{+}$ current (data not shown). The voltage-gated inward currents had an $I-V$ relationship similar to the antigen H-IR (type I) cells. Outward current profiles also resembled those of antigen H-IR cells, with slow activation and no inactivation with maintained depolarization. A few GFP-positive cells showed saturation of the outward current at depolarized potentials. None of the cells tested $(n=27)$ had voltage-gated $\mathrm{Ca}^{2+}$ currents (Fig. 5B).

Antigen A-expressing cells

Another population of type II cells was labeled with an antibody to the blood group marker antigen A (Pumplin et al., 1999). These cells were subdivided into two groups based on their current profiles: those with voltage-gated $\mathrm{Ca}^{2+}$ currents $(n=25)$ and those without $(n=17)$. Representative recordings from the cells lacking $\mathrm{Ca}^{2+}$ current are shown in Figure 6, $A$ and $B$. Approximately one-half $(n=8)$ of these cells had voltage-gated inward currents. The outward current profiles of these cells resembled those of gustducin-expressing cells and antigen H-IR cells in that they activated slowly and did not inactivate with maintained depolarization.

In comparing antigen H-IR cells, antigen A-IR cells without $\mathrm{Ca}^{2+}$ currents, and GFP-positive cells, there were few significant differences between these groups (Table 1). A larger percentage of GFP-expressing taste cells had inward current than did the other cell types, and the activation kinetics of outward current in gustducin-positive taste cells was slightly but significantly slower than other cell types.

The second group of antigen A-positive cells had large inward and outward currents (Fig. $7 A$ ) and voltage-gated $\mathrm{Ca}^{2+}$ currents (Fig. $7 B$ ). The inward current of these cells showed an $I-V$ relationship that was similar to that seen for the small inward currents of the other cell types, except that the peak currents were much larger (Fig. 7C). The outward currents activated more rapidly, and most inactivated with maintained depolarization compared with the current profiles of cells that lacked $\mathrm{Ca}^{2+}$ currents. All $\mathrm{Ca}^{2+}$ currents were measured in $\mathrm{Ba}^{2+}$ external solution, which shifted the voltage dependence of the channel in the hyperpolarizing direction compared with $\mathrm{Ca}^{2+}$ as a charge carrier (Hille, 2001).

General characteristics of type II cells are summarized in Table 1. Although the GFP-positive cells and the antigen A cells without $\mathrm{Ca}^{2+}$ current were not significantly different, the cells with $\mathrm{Ca}^{2+}$ currents did have significantly lower resting potentials, faster activation and inactivation of $\mathrm{K}^{+}$currents, as well as significantly larger $\mathrm{Na}^{+}$and $\mathrm{K}^{+}$currents compared with the other type II cells. These differences, in addition to the presence of $\mathrm{Ca}^{2+}$ channels in these cells, support the hypothesis that these cells are a separate subgroup of type II cells.

\section{Analysis of NCAM-IR cells}

All NCAM-positive cells $(n=10)$ had large inward and outward currents (Fig. 8A) as well as voltage-gated $\mathrm{Ca}^{2+}$ currents (Fig. $8 B$ ). These values were comparable with those of type II cells with voltage-gated $\mathrm{Ca}^{2+}$ channels (Table 1 ). When comparing cells with $\mathrm{Ca}^{2+}$ currents (both antigen A- and NCAM-IR) to those without, cells with $\mathrm{Ca}^{2+}$ currents had significantly larger inward and outward currents, and the outward current had faster activation kinetics and was much more likely to be inactivating than cells without $\mathrm{Ca}^{2+}$ current. However, general membrane properties, including resting potential and input resistance, were similar to other cell types (Table 1).

\section{Discussion}

Using recently identified external epitope markers (Pumplin et al., 1997) and transgenic mice expressing GFP under control of the gustducin promoter (Huang et al., 1999), we report here the first description of voltage-gated currents in defined mouse taste 
Table 1. Characteristics of each cell type

\begin{tabular}{|c|c|c|c|c|c|c|c|c|}
\hline Cell type & $\begin{array}{l}\text { Input resistance } \\
(\mathrm{G} \Omega)\end{array}$ & $\begin{array}{l}\text { Resting } \\
\text { potential (mV) }\end{array}$ & $\begin{array}{l}\text { Peak } \mathrm{Na}^{+} \\
\text {current }(\mathrm{pA})\end{array}$ & $\begin{array}{l}\text { Peak } \mathrm{Ca}^{2+} \\
\text { current }(\mathrm{pA})\end{array}$ & $\begin{array}{l}\text { Peak } K^{+} \\
\text {current }(\mathrm{pA})\end{array}$ & $T_{1 / 2}$ & $\begin{array}{l}\text { Percentage } \\
\text { inactivating }\end{array}$ & $\begin{array}{l}\text { Percentage } \\
\text { saturating }\end{array}$ \\
\hline Type I (antigen H-IR) & $1.13 \pm 0.08$ & $-37 \pm 2.7$ & $-166.6 \pm 29.2$ & & $665.7 \pm 101$ & 18.2 & $5 \%$ & $20 \%$ \\
\hline Type II (gustducin) & $1.42 \pm 0.14$ & $-45.5 \pm 2.9$ & $-286.6 \pm 38.9$ & & $847.5 \pm 80.7$ & 20.2 & $9 \%$ & $30 \%$ \\
\hline Type II (antigen A, no Ca current) & $1.18 \pm 0.08$ & $-43.7 \pm 3.1$ & $-322.2 \pm 71.8$ & & $735.9 \pm 99.1$ & 18.9 & $24 \%$ & $18 \%$ \\
\hline Type II (antigen A, with Ca current) & $1.17 \pm 0.08$ & $-33.2 \pm 2.0$ & $-606.9 \pm 48.2$ & $-178 \pm 35.6$ & $1715.4 \pm 149.9$ & 17.8 & $75 \%$ & $13 \%$ \\
\hline Type III (NCAM-IR) & $1.3 \pm 0.14$ & $-35.8 \pm 2.3$ & $-536.1 \pm 46.3$ & $-314.5 \pm 60.5$ & $1467.3 \pm 145.1$ & 17.5 & $86 \%$ & $14 \%$ \\
\hline
\end{tabular}

Average values for general electrophysiological characteristics of each cell type are shown. The input resistances of each cell type were not significantly different. However, the resting potential for type II cells with voltage-gated Ca ${ }^{2+}$ currents was significantly $(p<0.009)$ lower than the other type Il cells. In general, cells with voltage-gated $\mathrm{Ca}^{2+}$ currents had lower resting potentials and faster activation kinetics $\left(T_{1 / 2}\right)$, although this was not statistically significant. These cells also had significantly larger inward and outward currents $(p<0.007)$, and the outward current was more likely to be inactivating when compared with cells without $\mathrm{Ca}^{2+}$ currents.

cell types. Although GFP expression and the cell surface markers do not correlate perfectly with cell type, an approximation can be made on the basis of previous work in rats (Takeda et al., 1992; Pumplin et al., 1997, 1999; Yee et al., 2001). Although it is not likely that there are differences in cell type labeling between rats and mice, we cannot rule out this possibility. Based on the rat, antigen $\mathrm{H}$ labels primarily type I cells, antigen A labels only type II cells, and NCAM has been observed on type III cells. Our study shows that GFP expression is representative of gustducinexpressing cells, although its expression is not completely colocalized with gustducin-IR. These data also are not meant to imply that all cells in a given type are identified by these markers. It is possible that other unlabeled groups of cells exist in the taste bud. In addition, our double-labeling experiments suggest some minor overlap between antigen A and NCAM labeling. Because of the tendency of type I cells to envelop other cells in the taste bud (Pumplin et al., 1997, 1999), we were unable to verify the extent of overlap between antigen $\mathrm{H}$ and the other markers. However, no overlap was observed between GFP expression and antigen $\mathrm{H}$-IR in isolated cell experiments.

The principal finding is that taste cells have two distinct current profiles that correlate closely with the presence or absence of voltage-gated $\mathrm{Ca}^{2+}$ currents. Taste cells with $\mathrm{Ca}^{2+}$ currents have large rapidly activating voltage-gated $\mathrm{Na}^{+}$currents and $\mathrm{K}^{+}$currents that inactivate with maintained depolarization. This current profile occurs in a subset of type II cells and all NCAM-IR (type III) cells. These cells presumably can generate action potentials and are capable of releasing neurotransmitters. The cells lacking $\mathrm{Ca}^{2+}$ currents have smaller inward and outward currents, including some with no $\mathrm{Na}^{+}$current at all. These cells encompass all antigen H-IR (type I) cells and the remainder of type II cells, including the GFP-positive cells.

Resting potentials of isolated taste cells are lower than taste cells in vivo, in which the apical membrane is exposed to a low$\mathrm{Na}^{+}$environment. Although $\mathrm{Na}^{+}$currents of isolated taste cells would likely be inactivated at taste cell resting potentials, in situ recordings have shown that taste cells generate action potentials in response to taste stimuli (Avenet and Lindemann, 1991; Cummings et al., 1993; Ohtubo et al., 2001). Our data suggest that these electrically excitable cells are the subset of cells with large voltage-gated currents.

Although there was consistent labeling of cell surface markers in each preparation, it is not clear that all cells from a specific cell type were labeled by the markers used in this study. It is possible that additional subsets of cells with unique properties were not characterized. Additionally, the fluorescence generated by the GFP protein or the rhodamine-labeled antibodies conceivably could damage cells and reduce current magnitude. We do not believe this occurred for several reasons. First, cells were illuminated only briefly for identification and neutral density filters reduced light intensity. Second, we recorded large voltage-gated currents in antibody-labeled cells. Finally, similar current profiles were observed in many unlabeled cells that were not exposed to fluorescent illumination. Thus, it is unlikely that fluorescent illumination confounded our results.

Another concern is that antibodies directed against external epitopes may interact with voltage-gated channels and interfere with channel conductance. We think this is unlikely for the following reasons. First, all NCAM-IR cells had large inward and outward currents as well as calcium currents, indicating that antiNCAM was not blocking ion channels. Second, many antigen A-IR cells had current profiles similar to those of NCAM-IR cells, suggesting that anti-antigen A was not interfering with voltagegated currents. However, because all anti-antigen $\mathrm{H}$ cells had small currents, we examined the effect of this antibody on the current profile. Currents from isolated cells were characterized and then labeled with anti-antigen $\mathrm{H}$. The analyzed cells $(n=3)$ had the same current profiles as the prestained cells, suggesting that external antibodies did not confound our results.

Because taste cells turn over approximately every $10 \mathrm{~d}$, one question is whether the cells analyzed were mature taste cells capable of transducing taste stimuli. This is of more concern when looking at cells with small current profiles and no $\mathrm{Ca}^{2+}$ currents, because large currents imply electrical excitability and cell maturity. Previous work has shown that gustducin is not expressed before $2.5 \mathrm{~d}$ postmitotic (i.e., when a taste cell assumes a mature phenotype). Similarly, antigen A is expressed only on elongate taste cells assumed to be morphologically mature (Pumplin et al., 1999). Thus, the lack of $\mathrm{Ca}^{2+}$ currents and the small inward and outward currents found in these cells are not likely attributable to cell immaturity. The time course of antigen $\mathrm{H}$ expression has not been analyzed, so it is possible that some cells, particularly those lacking $\mathrm{Na}^{+}$current, were immature.

Antigen H-IR (type I) cells had small voltage-gated $\mathrm{K}^{+}$currents, with little or no $\mathrm{Na}^{+}$current. These cells may act as glia or supporting cells, because they tend to wrap around other cells in the taste bud (Pumplin et al., 1997) and express GLAST, a glutamate transporter found in glia (Lawton et al., 2000). A subset of mouse taste cells with a low input resistance and large resting potential was identified recently, and these "leaky" cells were suggested to be type I cells (Bigiani, 2001). Although some features of type I cells resemble leaky cells (i.e., small voltage-gated currents), we found no evidence of leakiness in any identified cell population. Leaky cells apparently do not express any of the external epitope markers used in this study.

Classical chemical synapses are usually associated with voltage-gated $\mathrm{Ca}^{2+}$ channels. The lack of voltage-gated $\mathrm{Ca}^{2+}$ currents in antigen H-IR (type I) cells suggests that these cells do not form synapses with nerve fibers; however, synapses have been reported from dark cells onto afferent nerve fibers in the mouse (Kinnamon et al., 1985, 1988). These ultrastructural studies identified cell type on the basis of cytoplasmic density, which can vary 
depending on fixation procedures (Cottler-Fox et al., 1987). Additional studies are needed to clarify this apparent discrepancy. Although the functional significance of type I cells is unclear, our data do not rule out a role for type I cells in taste transduction, particularly because voltage-gated currents for antigen $\mathrm{H}$-IR cells are not significantly different from GFP-positive (gustducinexpressing) cells that transduce bitter stimuli.

Type II cells were subdivided into three different groups: gustducin-expressing cells, antigen A-IR cells with $\mathrm{Ca}^{2+}$ currents, and antigen A-IR cells without $\mathrm{Ca}^{2+}$ currents. The gustducin-expressing cells and the antigen A-IR cells lacking $\mathrm{Ca}^{2+}$ currents had small inward and outward currents and no voltage-gated $\mathrm{Ca}^{2+}$ current. Most of the outward current in these cells was noninactivating, and the rise time to half-maximal activation was significantly slower than for other cell types tested.

The lack of $\mathrm{Ca}^{2+}$ current in gustducin-expressing taste cells is surprising, given that gustducin is involved in bitter-taste transduction (Wong et al., 1996; Chandrashekar et al., 2000), and this information must be transmitted to the nervous system. Our data suggest that gustducin-expressing taste cells may not communicate with the nervous system using conventional synapses. In addition to lacking voltage-dependent $\mathrm{Ca}^{2+}$ channels, gustducin-expressing taste cells lack the presynaptic protein SNAP-25 (K. Medler and S. Kinnamon, unpublished observations; R. Yang and J. Kinnamon, personal communication) that is correlated with the ultrastructural presence of synapses in taste buds (Yang et al., 2000a). The final step in bitter transduction involves $\mathrm{IP}_{3}$-mediated release of $\mathrm{Ca}^{2+}$ from intracellular stores followed by $\mathrm{Ca}^{2+}$ influx via storeoperated channels (Ogura et al., 2002). These mechanisms likely provide a sufficient increase in intracellular $\mathrm{Ca}^{2+}$ to facilitate vesicle release by a SNAP-25-independent mechanism. Anatomical studies in mouse foliate taste buds report the presence of subsurface cisternas and atypical mitochondria often associated with accumulations of vesicles that can be found at sites of nerve fiber appositions (Royer and Kinnamon, 1988). Whether such cisternas occur in gustducin-expressing taste cells and whether they are involved in intercellular communication remain to be determined. Whichever mechanism couples bitter transduction to the nervous system does not require voltage-gated $\mathrm{Ca}^{2+}$ channels in the taste transducing cells.

A second group of antigen A-IR (type II) cells had the same current profile as the NCAM-IR (type III) cells. These cells have large voltage-gated inward and outward currents as well as voltage-gated $\mathrm{Ca}^{2+}$ currents. At least $75 \%$ of both groups had an inactivating outward current, whereas $<25 \%$ of the other cell groups possessed this current. Immunocytochemical data show that the cells with $\mathrm{Ca}^{2+}$ currents form two distinct populations, one immunoreactive for NCAM (type III) and the other for antigen A (type II) (Fig. 1B). We conclude that these cells have the machinery necessary for electrical excitability and regulation of vesicle release at conventional synapses. Classical synapses with afferent nerve fibers have been observed with both type II (Kinnamon et al., 1988) and type III (Murray, 1969; Takeda et al., 1992) cells, although it is not known whether all cells with $\mathrm{Ca}^{2+}$ currents form classical synaptic contacts with nerve fibers. Two populations of type III cells have been identified; one expresses the neurotransmitter serotonin, whereas the other expresses the neuronal marker protein gene product (PGP) 9.5 (Yee et al., 2001). PGP 9.5 is also expressed on a subset of type II cells, which may be those with $\mathrm{Ca}^{2+}$ currents. Additional studies are needed to substantiate this.

The only previous study to correlate taste cell type with the presence of $\mathrm{Ca}^{2+}$ currents was performed with isolated Necturus taste cells, in which cell type was identified after recording by electron microscopy (McPheeters et al., 1994). In that study, $\mathrm{Ca}^{2+}$ currents as well as voltage-gated $\mathrm{Na}^{+}$and $\mathrm{K}^{+}$currents were observed in all type I cells and in a subset of type II cells. However, these previous data are not directly comparable with mammalian taste cells, because both type I and type II cells in Necturus taste buds form synapses with nerve fibers, and type III cells are not found in amphibians.

Whether taste cells with $\mathrm{Ca}^{2+}$ currents possess the transduction apparatus for any taste stimulus is unclear. Several taste receptors have been identified (for review, see Lindemann, 2001), but whether any of these receptors are in taste cells that express $\mathrm{Ca}^{2+}$ currents is unknown. Alternatively, these cells may not express taste receptors but may receive signals from neighboring cells that do express taste receptors. For example, the gustducinexpressing cells may not communicate directly with nerve fibers but rather with adjacent taste cells through neuromodulators, gaseous messengers, or gap junctions. Interestingly, taste cells have been shown to respond to the neurotransmitters serotonin (Herness and Chen, 2000), noradrenaline (Herness et al., 2002), acetylcholine (Ogura, 2002), and cholecystokinin (Herness et al., 2002). Additional studies are required to determine whether any of these mechanisms contribute to intercellular communication within the taste bud.

\section{References}

Avenet P, Lindemann B (1991) Noninvasive recording of receptor cell action potentials and sustained currents from single taste buds maintained in the tongue: the response to mucosal $\mathrm{NaCl}$ and amiloride. J Membr Biol 124:33-41.

Béhé P, DeSimone JA, Avenet P, Lindemann B (1990) Membrane currents in taste cells of the rat fungiform papilla. J Gen Physiol 96:1061-1084.

Bigiani A (2001) Mouse taste cells with glialike membrane properties. J Neurophysiol 85:1552-1560.

Chandrashekar J, Mueller KL, Hoon MA, Adler E, Feng L, Guo W, Zuker CS, Ryba NJP (2000) T2Rs function as bitter taste receptors. Cell 100:703-711.

Chen Y, Sun XD, Herness S (1996) Characteristics of action potentials and their underlying outward currents in rat taste receptor cells. J Neurophysiol 75:820-831.

Cottler-Fox M, Arvidson K, Hammarlund E, Friberg U (1987) Fixation and occurrence of dark and light cells in taste buds of fungiform papillae. Scand J Dent Res 95:417-427.

Cummings TA, Powell J, Kinnamon SC (1993) Sweet taste transduction in hamster taste cells: evidence for the role of cyclic nucleotides. J Neurophysiol 70:2326-2336.

Farbman AI (1980) Renewal of taste bud cells in rat circumvallate papillae. Cell Tissue Kinet 13:349-357.

Hamill OP, Marty A, Neher E, Sakmann B, Sigworth FJ (1981) Improved patch-clamp techniques for high-resolution current recording from cells and cell-free membrane patches. Pflügers Arch 391:85-100.

Herness S, Chen Y (2000) Serotonergic agonists inhibit calcium-activated potassium and voltage-dependent sodium currents in rat taste receptor cells. J Membr Biol 173:127-138.

Herness S, Sun XD (1995) Voltage-dependent sodium currents recorded from dissociated rat taste cells. J Membr Biol 146:73-84.

Herness S, Sun XD (1999) Characterization of chloride currents recorded from dissociated rat taste cells. J Neurophysiol 82:269-271.

Herness S, Zhao F, Kaya N, Lu S, Shen T, Sun XD (2002) Adrenergic signaling between rat taste receptor cells. J Physiol (Lond) 543:601-614.

Hille B (2001) Voltage gated calcium channels. In: Ion channels of excitable membranes, pp 95-129. Sutherland, MA: Sinauer.

Huang L, Shanker YG, Dubauskaite J, Zheng JZ, Yan W, Rosenzweig S, Spielman AI, Max M, Margolskee RF (1999) G $\gamma 13$ colocalizes with gustducin in taste receptor cells and mediates $\mathrm{IP}_{3}$ responses to bitter denatonium. Nat Neurosci 2:1055-1062.

Kinnamon JC, Taylor BJ, Delay RJ, Roper SD (1985) Ultrastructure of mouse vallate taste buds. I. Taste cells and their associated synapses. J Comp Neurol 235:48-60. 
Kinnamon JC, Sherman TA, Roper SD (1988) Ultrastructure of mouse vallate taste buds. III. Patterns of synaptic connectivity. J Comp Neurol 270:1-10.

Lawton DM, Furness DN, Lindemann B, Hackney CM (2000) Localization of the glutamate-aspartate transporter, GLAST, in rat taste buds. Eur J Neurosci 12:3163-3171.

Lindemann B (2001) Receptors and transduction in taste. Nature 413:219-225.

McPheeters M, Barber AJ, Kinnamon SC, Kinnamon JC (1994) Electrophysiological and morphological properties of light and dark cells isolated from mudpuppy taste buds. J Comp Neurol 346:601-612.

Murray RG (1969) Cell types in rabbit taste buds. In: Olfactory and taste, Vol III (Pfaffmann C, ed), pp 331-344. New York: Rockefeller UP.

Murray RG (1973) The ultrastructure of taste buds. In: The ultrastructure of sensory organs (Friedmann I, ed), pp 1-81. Amsterdam: North Holland.

Nelson GM, Finger TE (1993) Immunolocalization of different forms of neural cell adhesion molecule (NCAM) in rat taste buds. J Comp Neurol 336:507-516.

Ogura T (2002) Acetylcholine increases intracellular $\mathrm{Ca}^{2+}$ in taste cells via activation of muscarinic receptors. J Neurophysiol 87:2643-2649.

Ogura T, Margolskee RF, Kinnamon SC (2002) Taste receptor cell responses to the bitter stimulus denatonium involve $\mathrm{Ca}^{2+}$ influx via storeoperated channels. J Neurophysiol 87:3152-3155.

Ohtubo Y, Suemitsu T, Shiobara S, Matsumoto T, Kumazawa T, Yoshii K (2001) Optical recordings of taste responses from fungiform papillae of mouse in situ. J Physiol (Lond) 530:287-293.

Pumplin DW, Yu C, Smith DV (1997) Light and dark cells of rat vallate taste buds are morphologically distinct cell types. J Comp Neurol 378:389-410.

Pumplin DW, Getschamn E, Boughter JD, Yu C, Smith DV (1999) Differ- ential expression of carbohydrate blood-group antigens on rat taste-bud cells: relation to the functional marker $\alpha$-gustducin. J Comp Neurol 415:230-239.

Royer SM, Kinnamon JC (1988) Ultrastructure of mouse foliate taste buds: synaptic and nonsynaptic interactions between taste cells and nerve fibers J Comp Neurol 270:11-24.

Smith DV, Akeson RA, Shipley MT (1993) NCAM expression by subsets of taste cells is dependent upon innervation. J Comp Neurol 336:493-506.

Smith DV, Klevitsky R, Akeson RA, Shipley MT (1994) Expression of the neural cell adhesion molecule (NCAM) and polysialic acid during taste bud degeneration and regeneration. J Comp Neurol 347:187-196.

Takeda M, Suzuki Y, Obara N, Nagai Y (1992) Neural cell adhesion molecule of taste buds. J Electron Microsc (Tokyo) 41:375-380.

Wladkowski SL, Lin W, McPheeters M, Kinnamon SC, Mierson S (1998) A basolateral chloride conductance in rat lingual epithelium. J Membr Biol 164:91-101.

Wong GT, Gannon KS, Margolskee RF (1996) Transduction of bitter and sweet taste by gustducin. Nature 381:796-800.

Wong GT, Ruiz-Avila L, Margolskee RF (1999) Directing gene expression to gustducin-positive taste receptor cells. J Neurosci 19:5802-5809.

Yang R, Crowley HH, Rock ME, Kinnamon JC (2000a) Taste cells with synapses in rat circumvallate papillae display SNAP-25-like immunoreactivity. J Comp Neurol 424:205-215.

Yang R, Tabata S, Crowley HH, Margolskee RF, Kinnamon JC (2000b) Ultrastructural localization of gustducin immunoreactivity in microvilli of type II taste cells in the rat. J Comp Neurol 425:139-151.

Yee CL, Yang R, Bottger B, Finger R, Kinnamon JC (2001) “Type III” cells of rat taste buds: immunohistochemical and ultrastructural studies of neuron-specific enolase, protein gene product 9.5, and serotonin. J Comp Neurol 440:97-108. 